\title{
Profit Maximization in Islam
}

\author{
Sonia Ghori \\ Department of Business Administration \\ Sindh Madressatul Islam University \\ Karachi, Pakistan \\ E-mail: sonia.ghori.88@gmail.com
}

Received: August 03, 2020

doi: I0.4628I/ijibfr.v4i2.767
Accepted: August 30, 2020

Online Published: SeptemberI6, 2020

URL: https://doi.org/I0.4628I/ijibfr.v4i2.767

\begin{abstract}
The Islamic financial system is based on the betterment of society. It discourages any discrimination among the people and promotes equal distribution of wealth among the people. This study aims to investigate the concept of Profit maximization in Islam by taking evidence from the Quran, authentic Hadith, and Islamic scholars Fatwa. The center discussion of this paper would be based on theoretical aspects. Islam promotes the idea of business and trade, business profits, and motivates them to search and strive for 'halal' profit. This can be proved by different Quranic Verses and Hadith and Fatwa. The study also has a great example of our Holy Prophet (P.B.U.H). The convention of many hadith with the profit as a benchmark may be used as an alternative to interest in Islamic financing. The study is an effort to discuss the features of the Islamic concept of profitability and distinguish between halal and haram profit and discussed the questions to which extent profit is acceptable for Muslims.
\end{abstract}

Keywords: Business, Halal, Profit, Riba, Trade.

\section{Introduction}

Modern business set up and the capitalist system promotes selfishness, materialistic approach and their focus are only for-profit maximization. They do not even know to what extent the profit is fair for any businessman. As a result, we can see that everyone is running towards profit maximization. Muslim scholars have discussed that unfair profit which crossed the limits of the Islamic perspective is not acceptable. Now the question arises what the limitation of profit is and what are the important rules which should be followed by a Muslim businessman to attain the maximum success and spend his life according to the will of Allah. Quran is the hallmark and guideline for every aspect of life. To have a thorough understanding of the Shariah is the most important to look at the authentic hadith, qur'anic verses, and fatwa by Islamic scholars that deal with profits maximization.

\section{Literature Review}

With the purpose to go into the general standardization of Islamic financing, it is significant to examine the authentic hadith on business and profit. Honesty, safety, kindness, and fair dealings towards customers are the essence of business. One who does not follow the dominance and superiority of Allah in every aspect of life cannot be a good Muslim and thus blocks his livelihood.

Hassan (2008) Private sector in the Kingdom of Saudi Arabia tends towards profit maximization instead of Islamic rules for profitability.

Chapra (20II) and Islam (2017) states that profit maximization leads towards an unfair business whereas Almighty Allah has given clear instructions in the Quran. We have made you a middle way nation.

Dr. Rehman\& Zada N. (2014) Profit maximization is not negative but what it makes negative is the way it is earned or the way it is spent, in short, the sources of earning and spending money depends on haram profit, not the profit quantity.

\section{Definition of Profit}

Basically, as per the barter concept: "Profit is an individual's opinion of the increase of total utility, use fullness, or value-in-use that is his as the result of an exchange." Hence, Profit is not a thing, nor is it a specific condition among things; it is an intellectual concept only and varies from person to person and from time to time. 
Profit quantitatively expressed: "Profit is the excess of the price received in bargaining exchange s over the prices previously given."

4. Hadiths and Qur'anic Verses on Trade and Profitability

There is no ruling in the Quran and Hadith about Profit margin limits.

Abu Huraira narrated that the Prophet said: "A time will come upon the people when one will not care how one gains one's money, legally or illegally". (Bukhari)

Jabir narrated that the Prophet (Peace and blessings of Allah be upon him) said:

"May Allah show mercy to a man who is kind when he sells, when he buys, and when he makes a claim". (Bukhari)

\section{Hadith on Profit Distribution Among Partners}

"Profit return is shared according to condition determined freely by partners. And the loss is dealt with according to the ratio of their capitals.” (Ibn e Majah, Tijarat63).

The Prophet has got many remarks, actions, and statements related to commercial and financial life. When the Messenger of Allah was asked what the best way of livelihood was, he answered: "It is one's elbow grease and acceptable trade." (Ahmad bin Hanbal, Musnad,3/466). "Truth and the trustworthy trader will be with martyrs at the Day of Judgment."

Some of the advice of the Messenger of Allah to tradesmen is as follows:

"A trade's man who is straight (honest) both in his words and actions is in the shadow of the sky on the Day of Judgment." (Ibn e Majah, CommerceI)

"O community of tradesmen! Doubtlessly, there are a lot of lies in trade. For this reason, compensate for it with sadaqah." (Abu Dawud)

"A tradesman who is reliable in his words and actions is with prophets, the Siddiq and martyrs." (Tirmidhi)

Usually, it is assumed that there are no limits to profits from the Islamic perspective. Furthermore, Islam has discouraged trading without profits in many Quranic verses.

The Holy Qur'an (62:10)

Then once the Salah is over, disperse in the land, and seek the grace of Allah, and remember Allah abundantly, so that you may be successful.

$\mathrm{Al}$ Quran (2:275)

"While Allah has permitted the sale and prohibited riba."

Al Quran (2:198)

There is no sin on you that you seek the grace of your Lord (by trading).

Al Quran (2:278)

O you, who believe, fear Allah and give up what remains of riba if you are believers

Allah spoke disparagingly of certain people in the Qur'an:

(Al Quran 2:16) "Their trade reaped no profit."

\section{Evidence from History}

The name of HazratKhadeeja (R.A) was a famous trader in Tarateebuladariya. She was a very wealthy and well-known merchant at that time. She used to send some people to sell her goods in different countries like Syria, sham, Yemen.

Once she offered Hazrat Muhammad (Peace and blessings of Allah be upon him) to sell her goods in sham and said that she will give twice the profit in comparison to others. So Hazrat Muhammad (SAW) went Sham with Hazrat Khadija's slave Maysarah to sell goods and Hazrat Muhammad Peace \& blessings Of Allah be upon him sold all goods and came back and receive twice the profit as Hazrat Khadija (RA) offered.

\section{Fatwa Regarding Profit in Islam \\ 7.I Fataawa al-Lajnah al-Daa'imah: (I3/9I)}

Profits in business are not limited, rather they depend on supply and demand, plenty, and scarcity. But it is good for the Muslim, whether he is a trader or otherwise, to be easygoing in buying and selling, and not to take advantage of his companion's negligence to deceive him when buying or selling. Rather he should pay attention to the rights of the Islamic brotherhood.

\subsection{Fatawa Al-Lajnah Al-Daa'imah: (13/92)}

The earnings a trader may make are not limited by the shari'ah, but it is not permissible for a Muslim to cheat those who buy from him and to sell his goods at a price that differs from the going rate in the marketplace. Islam teaches Muslims not to seek a 
huge profit, but to be easygoing when buying and selling because the Prophet (peace and blessings of Allah be upon him) urged an easygoing and tolerant attitude in dealings with others.

\section{Some Example of Profit Making Against Buying and Selling in Islam}

The owner has a right to sell his goods at any rate until he does not force buyers. For example, If I sell my watch in Rupee one hundred thousand which is available in the market in just Rupee five thousand. If someone wants to buy this watch he/she can buy it. I am not forcing anyone. No one can ask me that I am selling this watch at a higher price. I am selling this watch at Rupee one hundred thousand because I bought it from Makah Mukaramah. This watch belongs to Makah Mukaramah sanctity therefore I will keep it with me, but if someone wants to buy this watch in Rupee one hundred thousand due to Makah sanctity. I can put that money to perform Umrah then I will sell my watch otherwise not. ${ }^{(I)}$

According to AllamabaghviRehmatullilah:

الخمست نقداً نساوى ستتر مو جلتح

Interpretation: It is equal to sell goods for Rupee five on cash and Rupee six on credits.

According to AllamabaghviRehmatullilah:

الآجلياءخذقسطاًمنالثمن

Duration Becomes part of the original price.

Example,

If a person wants to buy a watch from a shopkeeper of the market at rupees five thousand but if the shopkeeper says that I will sell this watch at Rupees Five thousand on cash and Rupee six thousand on credit for six months because he has to wait for full payment for six months. Therefore, one thousand extra profit is legal because it is for the watch not for duration. (2)

\section{Price Can Be Increased but Demand for Extra Profit Cannot Be Increased}

If someone trading on cash at a fixed price and for credit payment increase in its original price if buyers pay late then that increased price called interest.

For example, if a seller says that I sell such good in Rupees eight in cash but if you pay the amount after one month then you must pay two rupees more. Now, these two rupees more interest, because its original price is Rupees eight and, demanding of rupees two more is interest as per shariah. But if a buyer purchases such good at rupees ten on credit for a month, and he fails to pay in a month and pays after two months still he has to pay ten-rupee because the price has been set before full payment. ${ }^{(3)}$

For Example, if a person says that the market price of this watch is Rupee five thousand, but I will sell it in rupee six thousand because I purchased it from the market. If you can purchase it from the market you first go to the market spend some time and some money on conveyance, then you will find out that watch. And I am selling you at your home that is why I am selling this watch at rupee six thousand. And this extra one thousand is legal in Islam because the price has been set before payment. ${ }^{(4)}$

For example, if a person says that the market price of this watch is Rupee five thousand, but I will sell it in rupee six thousand because I purchased it from the market. If you can purchase it from the market you first go to market spend some time and some money in conveyance, then you will find out that watch. And I am selling you at your home that is why I am selling this watch at rupee six thousand. And this extra one thousand is legal in Islam because the price has been set before payment. ${ }^{(5)}$

\section{I0. Prohibited Forms of Business}

\section{IO.I Monopolistic Form of Business}

Islam discourages any harmful activities for society. A monopoly means putting the resources is in hand which causes disturbance in the supply of goods. It gives a chance to gain more profit because in the absence of competition high prices are charged on low-quality products. Maximization is the target of the capitalist system whereas the exploitation of consumers is declared to be unlawful in Islam.

\footnotetext{
(I) Islam or JadeedMuashiMasail Vol. 2 Pg. 47

Islam or JadeedMuashiMasail Vol. 2 Pg. 48-49

Islam or JadeedMuashiMasail Vol. 3 Pg. 94-95

Islam or JadeedMuashiMasail Vol. 2 Pg. 48

The Book of Transactions (Kitab Al-Buyu)
} 


\subsection{Artificial Scarcity of Commodities}

Speculation is disliked by Islam as the speculators purchase the goods in bulk at a very low price and sell these commodities at higher prices. The motive is to make maximum profit from fluctuations in the market. It refers that limited goods which may have the following effects.

- It Increases the cost

- It leads towards fighting instead of sharing.

- Artificial scarcity is imposed on the common people by the rich people who want to rule the markets.

\section{I0.3 Interest Transaction}

Interest or Riba is prohibited. Islam promotes the concept of investing in the business and earn a profit. The predetermined rate in Islam is not applicable whereas in trading a person can earn a profit after bearing the risk. It leads to the level of maximum investment and full employment the rate of interest is fixed and puts the maximum burden on the trader, moreover, it creates an economic crisis, and the rich become richer and the poor become more poor day-by-day.

\section{I0.4 Transactions Similar to Gambling}

Gambling was common among the Arabs before the advent of Islam and they were gambling by casting arrows drawn from a bag 'as a result, one was the loser and the other won prizes. It makes a person to rely on chances and luck with putting any efforts 'Shaytaan wants to excite enmity and hatred between you with intoxicants and gambling and hold you away from salat and Allah. So, will you not then abstain? ${ }^{(6)}$

\section{I0.5 Forced Selling}

Islam Prevent us from forced selling such as hoarding, speculating, exploiting, temping manipulating the prices in the market. As Abu Dauwd and others said that,

Allah says: And do not forget liberality between yourselves' and those who are under compulsion (of force or necessity) will be bought from. The Prophet (Peace and blessings of Allah be upon him) forbade forced sales, transactions of ambiguity, and selling crops before they have. ${ }^{(7)}$

As Abu Dauwd and others said that,

Allah says: And do not forget liberality between yourselves' and those who are under compulsion (of force or necessity) will be bought from. The Prophet (Peace and blessings of Allah be upon him) forbade forced sales, transactions of ambiguity, and selling crops before they have. ${ }^{(8)}$

\section{Prevent Exploitation}

Commercial activities that are done to maximize the profit $\&$ have no concern for the people are discouraged and Islamic principles are considered lawful. Islam prevents us to exploit someone just to make an excessive profit. Islam has aimed to promote the concept that Almighty Allah is the supreme power and we all are answerable for every act. So, we should stop them from taking advantage of people's needs. The Hadith narrated by al-Bukhari and others mentions that the Prophet (Peace and blessings of Allah be upon him) gave Urwah one dinar to purchase a goat. Urwah then bought two goats with that one dinar. Afterward, she sold one o the goats for one dinar. He came back to the Prophet (Peace and blessings of Allah be upon him) with a goat and one dinar. The Prophet (Peace and blessings of Allah be upon him) then prayed that he be blessed in his trading.

\section{Profitability and Payment of Wages/Salaries}

Businessmen, to raise profitability to minimize the wages or in other words exploit the employees Islam emphasizes fair relationship with workers, and if the employee is satisfied This Results in An Increase in Production and Level of Profitability.

\section{Elements of Fraud}

All the doors of dishonesty and fraud have closed in Islam, even the Muslim traders are instructed to describe the defect of their product and sell at a low price. Islam referred to consumer rights. The holy prophet said,

"The buyer and seller have the option of canceling the contract as long as they have not separated; then if they both speak the truth and manifest; their transaction will be blessed."

In the light of the Quran and Sunnah, the scholars proposed that the profit rate should not be more than one-third, which means "One-third is enough."

(6) (Sunan Abu Dawud Vol. 4 chapter 25 Pg85

${ }^{(7)}$ MustadrakulSunan Abu Dawud Vol. 4 chapter 25 Pg85)

${ }^{(8)}$ Wasa'il Vol. 2 Pg $3 I 4$ 


\section{I4. Hoarding}

Hoarding means stockpiling accumulating food, or other general items may also include worthless items. Allah forbade us to hoard in the Quran many times that telling hoarding gives no benefit at all.

The Prophet (peace and blessings of Allah be upon him) also says that one who hoards some goods for forty days will not be able to perceive the fragrance of Paradise, while the fragrance of Paradise reaches up to a distance of five hundred year's journey. When even the fragrance of Paradise is prohibited to him there is no question of his entering Heaven.

He also said that only the sinful people resort to hoarding goods. Also that if a person buys food items and hoards them for forty days so that prices rise in the Muslim markets, he has committed such a serious sin that if he were to later sell all the hoarded material and donate all the income it will not expiate for his sin. ${ }^{(9)}$

The Prophet (Peace and blessings of Allah be upon him) said:

"One who keeps an eatable in store for 40 nights (while it is needed) and Allah makes him away from Himself." (I0)

The Prophet (Peace and blessings of Allah be upon him) said:

"Whoever buys an eatable product, should not sell it to someone else until he receives it." (9)

Profit earning is legal in trading but has some professional etiquettes like trust, truthfulness, tempt, Facilitation, and great heartedness for others. In Islam, there are three sorts of profit.

- Legal

- Illegal

- Trading in which there is doubt either it's legal or illegal.

In shariah, there is not any written upper limit of profit that can be illegal. What is more, it depends on trading conditions, geographical locations, time, and supply and demand, and so on. There are some principles for earning profit in shariah.

- There must not an element of interest in Profit.

- There must not be a hoarding element in Profit.

\section{Profit Theories, A Comparison of Modern and Islamic}

The Islamic concept of profitability is not for a time or an era, but it is universal and for all ages. We can easily compare the theory with modern economic theory. The following points easily enlighten the characteristics of modern theories and the Islamic theory of Profitability Profit is a reward for bearing risk.

The modern theory states that profit is a reward for risk-taking, the higher the risk, the greater the return would be. This theory was given by F.B Hawley and he states that Profit is a reward for the assumption of risks by the entrepreneur This theory was criticized. Although profit contains some remuneration for risk-taking profit arises because of some managerial skills and other factors which are neglected in this theory. Islam allowed us to take risks to some extent. Companions of the Holy Prophet traveled towards far areas to explore new markets and increase their profits.

\section{I5.I Risks}

Risks in any business are of two things, that is the risk of loss of property due to natural calamity and risk of dishonesty such as theft, robbery Modern theory emphasizes on insurance, but Islam prohibits insurance. Non -insurable risks are competition and government policies such as price control, import and export, And customer trends, etc.

\section{I5.2 Un-Certainty Theory of Profit}

According to Knight 'Profit is a reward for bearing uncertainty and not of risk-taking in business. He introduced two types of risks in a business, but this theory was criticized that it is not uncertainty, but other factors also influence the entrepreneur and must be considered as an important factor.

\section{I5.3 Rent-Theory}

This theory was given by Francis. A. Walker. According to this theory, profit is rental just as superior grades of land earns more rent as superior entrepreneurs earn more profits This theory also focus on the concept of a marginal entrepreneur whose ultimate receipts from the sale covers his total cost This theory was criticized by Alfred Marshal who states that "There is a huge difference between the rent of land and profit".

AhmadbinHanbal, Musnad

Bukhari, 54, 55 
Moreover, this theory does not throw light on the nature of profit. Islam has given a separate theory of rent and Ijaarah under different circumstances and declares that rent is different from profit.

\section{I5.4 Marginal Productivity Theory}

Champmon states that the earning of an entrepreneur is like the reward of other factors of production and can be explained by the marginal productivity analysis. This theory was criticized because it is difficult to ascertain the marginal net productivity of labor. Islam has given the concept of better relationships with the workers and stresses to pay the wages immediately. The concept of teamwork was promoted by Islam to increase the efficiency level and increase in production

\section{I5.5 Dynamic Theory of Profit}

J.B C states' Profit arises only in a dynamic economy when there is a change in population growth or changes in consumer's wants. This theory was criticized as it is wrong to attribute all profits to dynamic changes. Islam has given the most dynamic theory which can be applied forever

Profit due to the market imperfection

Kalock's theory has stated that profit arises from dynamic changes such as changes and making a correct estimate of future conditions but monopolistic competition gives us profit This theory was criticized as it cannot replace other theories Monopolistic firms restrict output and obtain high profit but monopoly is restricted in Islam as this is harmful to the consumers.

\section{Profit as A Reward for Innovation}

Islam also allowed bringing innovations and thinking critically on every situation. Any purposeful change in production methods, organize new markets. Innovations in any business are allowed in the capitalist system but Muslims are restricted for only halal business.

\section{Profiteering and Profit -Earning}

Profiteering is not allowed in Islam when profit exceeds socially acceptable limits by adopting wrong and un-fair methods it is called profiteering such as artificial shortage and curtailing production. Profit earning is appreciated by adopting the limitations of our religion. In short, we can say that theories of profits given by different economists are failing to think about the welfare of people, but the Islamic concept can sustain in the world with a blend of welfare.

\section{I8. Conclusion}

The study concludes that all theories are defensive, and they are criticized by different economists as they reflect one aspect and neglect the other aspects. No one is perfect but the concept given by Almighty Allah is comprehensive and no one can give a better theory than the Islamic theory of profit. Islam has given the concept of profit maximization with a blend of ethical values and develops the concept of fair dealing and the well-being of society. It can be concluded with the help of the following points: Islam prohibits engaging in any haram business activity such as alcoholic drinks, production or sale of pigs, gambling, forbidden speculation, etc.

Islam discourages the barriers to entry in other words monopoly is not liked by Allah.

Islam command Fair rules and honest dealings.

Islam forbid making plans to raise the price of products by hook or by crook.

Islam discourage any exploitation and discrimination.

In some cases, Profits are allowed even I00\%.

Wealth is a gift of God and Allah is the supreme power, so the business is trust in his hands

Islamic ethos is to be followed 'Let the buyer be informed. In the words of the Holy prophet "The best people are those who benefit others".

\section{References}

Al Quran.

Dr. Salihu, A. A. (20I I). Concept of Profit Maximization Model in Islamic Commercial Banking. Arabian Journal of Business and Management Review, I (3).

Hasan, Z. (2008). Theory of profit from Islamic perspective. International Islamic University, Malaysia (IIUM).

Imam Hafiz Abu Dawud, S. B. (2008). Sunan Abu Dawud (Vol. 4). (H. K. Hafiz Abu Tahir Zubair All Zai, Ed., \& N. a.-K. (Canada), Trans.) Maktaba Dar-us-Salam.

Islam, K. M. A. (2017). Finance: An Islamic Perspective. International Journal of Islamic Banking and Finance Research, I(I), I-5. https://doi.org/I0.4628I/ijibfr.vIiI.32 
Kandhelvi, S. M. (1979). Fazail-e-Tijarat. Karachi, Sindh, Pakistan: Maktabul Shaikh.

METWALLY, D. M. (n.d.). A BEHAVIOURAL MODEL OF ISLAMIC FIRM. International Center for Research in Islamic Economics .

Rosman, I. B. (n.d.). Looking at an Islamic Investment: 'Cost of Capital' From.

Samdani, D. M. (2009). Gharar Ki Soraten (Kinds of Uncertainity). Karachi, Sindh, Pakistan: Quranic Studies.

Sulaiman D. Muhammad, M. U. (20I3). Distribution of Wealth an Islamic Perspective: Theoretical Consideration. World Applied Sciences Journal , 23 (8).

Usmani, M. T. (2008). Islam or Jadeed Maeeshat o Tijarat (Vol. 3). Karachi, Sindh, Pakistan.

Usmani, M. T. (2008). Islam or Jadeed Maeeshat o Tijarat (Vol. 2). Karachi, Sindh, Pakistan.

Usmani, S. u. (2008). Islam or Jadeed Maeeshat o Tijarat (Vol. 2). Karachi, Sindh, Pakistan.

\section{Copyrights}

Copyright for this article is retained by the author(s), with first publication rights granted to the journal. This is an open-access article distributed under the terms and conditions of the Creative Commons Attribution license (http://creativecommons.org/licenses/by/4.0/). 